\title{
Design of a Modified Charcoal Production Kiln for Thermal Therapy and Evaluation of the Charcoal Characteristics from this Kiln
}

\author{
Hui Su Lee, ${ }^{\text {a }}$ Woo Seok Jeon, ${ }^{\text {a }}$ Yun Ki Kim, ${ }^{\text {a }}$ Byantara Darsan Purusatama, ${ }^{\text {a }}$ \\ Ah Ran Kim, ${ }^{\mathrm{a}}$ Jae Ik Cho, ${ }^{\mathrm{a}}$ Wae Jung Kim, ${ }^{\mathrm{b}}$ Hyung Chun Kim, ${ }^{\mathrm{c}}$ and Nam Hun Kim ${ }^{\mathrm{a}, *}$
}

A modified charcoal kiln was developed for both thermal therapy and charcoal production. The design of a modified kiln for thermal therapy focused on safety and cleanliness, plus the production of good quality charcoal. Two entrances in the kiln were designed for convenient charcoal production and thermal therapy. A barrier wall designed for noxious gases was installed between the adjoining charcoal kilns for safe thermal therapy. Additionally, a fine dust collector was installed to remove the fine dust generated during charcoal production. To verify the safety of the kiln, fine dust and harmful gases, such as carbon monoxide $(\mathrm{CO})$, carbon dioxide $\left(\mathrm{CO}_{2}\right)$, nitrogen dioxide $\left(\mathrm{NO}_{2}\right)$, and radon $(\mathrm{Rn})$, were measured after the charring process. The quality of the charcoal produced in the thermal therapy kiln was also examined. To evaluate charcoal quality, some physical properties and results from a proximate analysis were evaluated using Korean standards. The measurements of harmful substances and fine dust in the modified charcoal kiln met the criterion of the Ministry of Environment Clean Air Conservation Act in Korea. In addition, there were no noticeable differences in the monthly charcoal characteristics prepared from the thermal therapy kiln, and the charcoal characteristics also met the reference values of the Korea Forest Service.

Keywords: Charcoal kiln; Charcoal quality; Fine dust; Proximate analysis; Thermal therapy

Contact information: a: Department of Forest Biomaterials Engineering, College of Forest and Environmental Sciences, Chuncheon 24341, Republic of Korea; b: Institute of Forest Science, Kangwon National University, Chuncheon 24341, Republic of Korea; c: College of Pharmacy, Kangwon National University, Chuncheon 24341, Republic of Korea;

* Corresponding author: kimnh@kangwon.ac.kr

\section{INTRODUCTION}

Currently, the charcoal industry in South Korea is in crisis due to a lack of competitiveness that is the result of an increase in imported charcoal and rising material expenses (Kim 2015). In addition to charcoal production, traditional charcoal kilns can be used for thermal therapy using residual waste heat after charcoal production, which can contribute additional benefits for charcoal producers.

In Korea, especially thermal therapy in charcoal kilns after charcoal production is used for a traditional medical treatment that seeks to stimulate physiology activity using the effect of the far-infrared rays from the materials of charcoal kilns. Objectives include pain relief, relax muscle spasms, enable efficient repair of muscle fibers and increasing blood-flow and metabolic cellular activity. However, no scientific evidence has been presented up to this point on the effect of far-infrared rays on the above symptoms.

Recently the authors demonstrated that the optimal thermal therapy using far-infrared rays (FIR) protected against acute restraint stress and recognition memory impairment (Mai et 
al. 2018a,b). For instance, the research showed that exposure to FIR attenuated acute restraint stress via up-regulation of glutathione peroxidase-1 (GPx-1) gene (Mai et al. 2018a). In addition, it was reported that the FIR-mediated inhibition of protein kinase C-delta (PKC $\delta$ ) facilitated extracellular signal-regulated kinase 1/2 signaling process through the interactive modulation between M1 muscarinic acetylcholine receptor (M1 AChR) and nuclear factor erythroid 2-related factor 2 (Nrf-2) transcription factor, which might ameliorate memory dysfunction induced by psychostimulant (Mai et al. 2018b). Therefore, it is proposed here that FIR-mediated neuropsychoprotective potential (i.e., anti-stress and cognitive enhancing effects) requires specific molecular targets, such as GPx-1 gene, PKC $\delta$ gene, and Nrf-2 transcription factor.

Therefore, thermal therapy must be an effective alternative to encourage the competitiveness of the charcoal industry in Korea. However, there are some problems with using traditional charcoal kilns for thermal therapy, such as safety, cleanliness, and the production of harmful gases. In this study, a modified charcoal kiln was developed for use in thermal therapy. To verify the safety and cleanliness of the kilns used for thermal therapy, the amount of harmful substances and fine dust produced from a traditional charcoal kiln and a modified kiln were measured. The physical properties and results from a proximate analysis of the charcoal produced from both kilns were compared. The charcoal characteristics produced monthly in thermal therapy kilns were also investigated.

\section{EXPERIMENTAL}

\section{Materials}

Charcoal produced from a traditional kiln and a thermal therapy kiln (Daemyung co, Jincheon, South Korea) was used to analyze its physical properties and for a proximate analysis. Charcoal samples were kept in a conditioned room with $60 \%$ R.H. at room temperature until providing experiment. The thermal therapy kiln was constructed with red clay, red clay bricks, and ceramic bricks (purchased from a market in Jincheon County, South Korea) as the main materials.

\section{Methods}

\section{Preparation of a modified kiln}

The charcoal kilns used for thermal therapy in this study were fitted with two doors, a fine dust collector, and noxious gas barriers between the kiln walls. The emission of farinfrared radiation and radiation energy of the materials, such as red clay, red clay bricks, and ceramic bricks, were examined using an Fourier transform infrared (FTIR) spectrometer (TSI7545; Teledyne, Thousand Oaks, CA, USA; T300; Teledyne, Thousand Oaks, CA, USA; T200; Sun NuClean 1028, Melbourne, FL, USA) at the Korea Far Infrared Association (KFA; Seoul, South Korea).

\section{Circumstance verification}

The harmful substances that were measured in the thermal therapy kiln included carbon monoxide $(\mathrm{CO})$, carbon dioxide $\left(\mathrm{CO}_{2}\right)$, nitrogen dioxide $\left(\mathrm{NO}_{2}\right)$, radon $(\mathrm{Rn})$, and fine dust in the kiln. The harmful substances were measured adjacent to the charcoal kiln during the charring process. Fine dust was measured inside the kiln at the top, middle, and bottom after operating the fine dust collector manufactured by a Shinpoong Co., Korea. 


\section{Comparison of charcoal properties between traditional and thermal therapy kiln}

The physical properties, such as density, moisture adsorption, calorific value, $\mathrm{pH}$, refining degree, and hardness of charcoal produced from the traditional kiln and thermal therapy kiln were examined. To measure the density of charcoal, the mass of the charcoal sample was measured, the surface of each sample was covered with paraffin, and the volume was examined using a mass cylinder. The moisture adsorption was measured in a desiccator with a relative humidity of $80 \%$ and controlled with a potassium chloride solution $(\mathrm{KCl})$ saturated solution according to Japanese standard JIS Z8806 (2001). To measure calorific value of charcoal, charcoal powder having a size of 60 mesh or less was prepared. After that, the calorific value of charcoal was measured with calorimetry (6300 Automatic Calorimeter, Parr Ltd., USA) after calibration using benzoic acid. For the measurement of $\mathrm{pH}$ values, charcoal powder having a size of 60 mesh was put into distilled water with the ratio of 1:100 (g, wt $\%)$ and heated for 10 minutes. After cooling at room temperature, the $\mathrm{pH}$ value was measured $(\mathrm{pH}$ meter, PB-10, Germany). The refining degree of charcoal was also measured by electrical resistance method (FA56, Samyang Electric Works, Japan). The hardness of charcoal was measured by using a hardness tester (Samyang Electric Works, Japan). The proximate analysis included the moisture content according to KS E ISO 589 (2017), ash content according to KS E ISO 1171 (2017), volatile matter according to KS E ISO 562 (2017), and fixed carbon according to KS E ISO (2012), which were compared to KS E (ISO 562 2017; ISO 589 2017; ISO 1171 2017).

\section{Comparison of charcoal characteristics from thermal therapy kilns over one year}

Proximate analysis as moisture content, ash content, volatile matter, and fixed carbon, and some physical properties as density, $\mathrm{pH}$, calorific value, refining degree, and hardness of the charcoal produced by the thermal therapy kilns were examined every two or three months from 2017 to 2018.

\section{RESULTS AND DISCUSSION}

\section{Design of the Thermal Therapy Kiln}

Figure 1 shows the structure of the modified charcoal kiln used for thermal therapy.

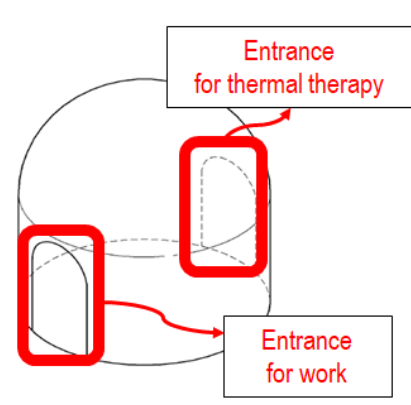

(1) Two doors

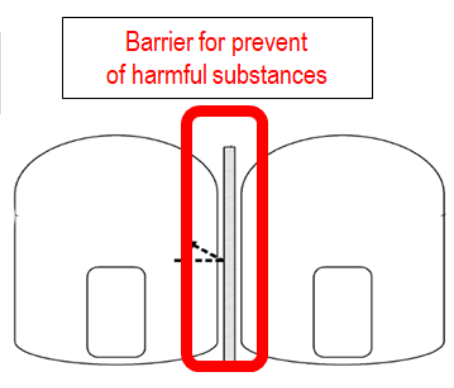

(2) Noxious gas barrier

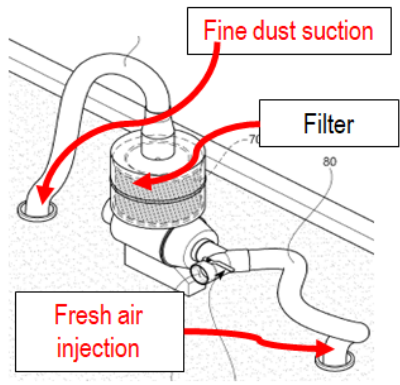

(3) Fine dust collector

Fig. 1. Schematic diagrams of a modified charcoal kiln used for thermal therapy 
Compared to the traditional charcoal kiln, which has a one-door structure, the safety and cleanliness of the modified kiln were improved by using a two-door structure to separate the entrances for the charcoal production and thermal therapy spaces. Noxious gas barriers were equipped between the kiln walls to block harmful gases such as $\mathrm{CO}, \mathrm{CO}_{2}$, and $\mathrm{NO}_{2}$. A fine dust collector was also installed to reduce the amount of fine dust released

Generally, red clay bricks and red clay are used as construction materials for traditional charcoal kilns. Leung et al. (2011) reported an average ceramic powder emissivity of 0.98 at wavelengths of $6 \mu \mathrm{m}$ to $14 \mu \mathrm{m}$, which represents an extremely high FIR intensity. Therefore, ceramic bricks that were specially prepared to raise FIR emission were used. The far-infrared emissivity and radiation energy of the ceramic bricks, red clay bricks, and red clay used in the modified kiln were measured at different temperatures and are shown in Table 1. The farinfrared emissivity and radiation energy values of the ceramic bricks were higher than those of the red clay bricks and red clay. The far-infrared emissivity and radiation values in all the materials decreased with increasing temperature.

Table 1. FIR Emissivity and Radiation Energy Values of the Kiln Construction Materials

\begin{tabular}{|c|c|c|c|c|c|c|}
\hline \multirow{2}{*}{$\begin{array}{c}\text { Temperature } \\
\left({ }^{\circ} \mathrm{C}\right)\end{array}$} & \multicolumn{2}{|c|}{ Ceramic Bricks } & \multicolumn{2}{c|}{ Red Clay Bricks } & \multicolumn{2}{c|}{ Red Clay } \\
\cline { 2 - 7 } & $\begin{array}{c}\text { FIR } \\
\text { Emissivity }\end{array}$ & $\begin{array}{c}\text { Radiation } \\
\text { Energy } \\
\left(\mathrm{W} / \mathrm{m}^{2} \mu \mathrm{m}\right)\end{array}$ & $\begin{array}{c}\text { FIR } \\
\text { Emissivity }\end{array}$ & $\begin{array}{c}\text { Radiation } \\
\text { Energy } \\
\left(\mathrm{W} / \mathrm{m}^{2} \mu \mathrm{m}\right)\end{array}$ & $\begin{array}{c}\text { FIR } \\
\text { Emissivity }\end{array}$ & $\begin{array}{c}\text { Radiation } \\
\text { Energy } \\
\left(\mathrm{W} / \mathrm{m}^{2} \mu \mathrm{m}\right)\end{array}$ \\
\hline 37 & 0.924 & $3.56 \times 10^{2}$ & - & - & - & - \\
\hline 100 & 0.916 & $7.87 \times 10^{2}$ & 0.910 & $7.82 \times 10^{2}$ & 0.908 & $7.80 \times 10^{2}$ \\
\hline 200 & 0.903 & $2.17 \times 10^{3}$ & - & - & - & - \\
\hline 300 & 0.892 & $4.92 \times 10^{3}$ & - & - & - & - \\
\hline 400 & 0.884 & $9.08 \times 10^{3}$ & - & - & - & - \\
\hline 500 & 0.879 & $1.50 \times 10^{4}$ & 0.868 & $1.48 \times 10^{4}$ & 0.861 & $1.47 \times 10^{4}$ \\
\hline
\end{tabular}

\section{Amount of Fine Dust and Harmful Substances}

Table 2 shows the amount of harmful substances and fine dust that were produced inside the charcoal kilns. According to the Clean Air Conservation Act (Ministry of Environment Act No. 13034 2015), fine dust should be kept below $150 \mu \mathrm{m} / \mathrm{m}^{3}$ in indoor spaces. The results showed that the amount of fine dust in the thermal therapy kiln was approximately a quarter of this reference value. The amount of fine dust was lowest in the middle of the thermal therapy kiln, and highest at the bottom of the kiln. Likewise, the amounts of harmful substances in the thermal therapy kiln, including $\mathrm{CO}_{2}, \mathrm{CO}, \mathrm{NO}_{2}$, and $\mathrm{Rn}$, were also below the reference values. The $\mathrm{CO}_{2}$ was approximately one-fifth of the reference value. The amount of $\mathrm{CO}$ in the thermal therapy kiln was below one-third of the reference value. The $\mathrm{NO}_{2}$ was especially reduced, with a value of $0.006 \mathrm{ppm}$, which was approximately a tenth of the reference value. The Rn concentration in the thermal therapy kiln was approximately one-fifth of the reference value. Consequently, the amount of fine dust and harmful substances in the kiln used for thermal therapy was below the standard values provided by the Clean Air Conservation Act (Ministry of Environment Act No. 13034 2015). 
Table 2. Amount of Fine Dust and Harmful Substances in the Kiln Used for Thermal Therapy

\begin{tabular}{|c|c|c|c|}
\hline Substances & Standard* $^{*}$ & Measured Position $^{* *}$ & Amount $(\mathrm{ppm})^{\text {Top }}$ \\
\hline Fine dust $\left(\mu \mathrm{g} / \mathrm{m}^{3}\right)$ & $<150$ & $\begin{array}{c}\text { Middle } \\
\text { Bottom }\end{array}$ & $\begin{array}{c}29 \text { to } 30 \\
20 \text { to } 23 \\
36 \text { to } 39\end{array}$ \\
\hline $\mathrm{CO}_{2}(\mathrm{ppm})$ & $<1,000$ & & 390 \\
\hline $\mathrm{CO}(\mathrm{ppm})$ & $<10$ & & 3.8 \\
\hline $\mathrm{NO}_{2}(\mathrm{ppm})$ & $<0.05$ & & 0.006 \\
\hline $\mathrm{Rn}\left(\mathrm{Bq} \mathrm{m}{ }^{3}\right)$ & $<148$ & & 29.1 \\
\hline
\end{tabular}

*: Clean Air Conservation Act, Ministry of Environment Act No. 13034 (2015); **: Measured position in the charcoal kiln for thermal therapy

\section{Comparison of Physical Characteristics of Charcoal from Both Types of Kilns}

Table 3 shows the density, moisture adsorption, calorific value, $\mathrm{pH}$, refining degree, and hardness of charcoal from a traditional kiln and a thermal therapy kiln. The charcoal density produced from both kilns was similar. The equilibrium moisture content (EMC) of charcoal at a relative humidity of $80 \%$ was $10.85 \%$ for the traditional kiln and $9.88 \%$ for the thermal therapy kiln. Thus, the charcoal EMC from both kilns were similar. The calorific values from both kilns were over $8,000 \mathrm{kcal} / \mathrm{kg}$.

According to the notification on specifications and quality Standards of charcoal in National Institute of Forest Science (NIFS) in Korea (2017), charcoal with calorific values above $7,800 \mathrm{kcal} / \mathrm{kg}$ is classified into the first class of charcoal quality. Therefore, the charcoal from the traditional and thermal therapy kilns had excellent calorific values. As a result, the calorific value of charcoal from both charcoal kilns met the notification on specifications and quality standards of charcoal.

The $\mathrm{pH}$ value of charcoal from both kilns was over 9. In general, charcoal characteristics are especially influenced by carbonization temperature. Jo et al. $(2007,2008)$ reported that the $\mathrm{pH}$ became more alkaline with increasing carbonization temperature. Kwon et al. (2012) also reported that the $\mathrm{pH}$ increased with increasing carbonization temperature from 7.6 at $400{ }^{\circ} \mathrm{C}$, to 9.7 at $1200{ }^{\circ} \mathrm{C}$. Recently, Hidayat et al. (2017) reported that charcoal produced at higher temperatures had a higher $\mathrm{pH}$. The refining degree and charcoal hardness from both kilns had the same values, which showed that the charcoal had excellent characteristics.

A refining degree that is closer to 0 is an indication of charcoal with good quality. Generally, the charcoal hardness indicates the surface condition, with higher numbers showing harder charcoal. In conclusion, the physical properties of charcoal produced from the traditional kiln and the thermal therapy charcoal kiln met the quality standards contained in NIFS in Korea (2017). 
Table 3. Physical Characteristics of Charcoal from Traditional Kiln and Thermal Therapy Kiln

\begin{tabular}{|c|c|c|c|}
\hline & QS & TK & TTK \\
\hline Density $\left(\mathrm{g} / \mathrm{cm}^{3}\right)$ & - & $0.45( \pm 0.07)$ & $0.47( \pm 0.04)$ \\
\hline $\begin{array}{c}\text { EMC at } 80 \% \text { Relative } \\
\text { Humidity }(\%)\end{array}$ & - & $10.85( \pm 0.07)$ & $9.88( \pm 0.04)$ \\
\hline Calorific Value $(\mathrm{kcal} / \mathrm{kg})$ & 1 class $>7,800$ & $8,139( \pm 41)$ & $8,059( \pm 0.02)$ \\
\hline $\mathrm{pH}$ & - & $9.29( \pm 0.06)$ & $9.59( \pm 0.02)$ \\
\hline Refining Degree & - & 0 to 1 & 0 to 1 \\
\hline Hardness & - & 12 & 12 \\
\hline
\end{tabular}

QS: Quality standards in NIFS in Korea (2017); TK: Traditional kiln; TTK: Thermal therapy kiln; values in parenthesis are the standard deviations

\section{Comparison of Proximate Analysis Values of Charcoal from Both Kilns}

Table 4 shows the proximate analysis values measured from the traditional and thermal therapy kilns for carbon, such as moisture content, ash content, volatile matter, and fixed carbon. The charcoal moisture content produced from the traditional charcoal and thermal therapy kilns were $9.80 \%$ and $9.15 \%$, respectively, which met the quality standards contained in NIFS in Korea (2017). The moisture content of the charcoal used in this study showed a slightly higher value than what was found in a previous study by Kwon et al. (2011). The ash content in both kilns showed similar values, $1.14 \%$ in the traditional kiln and $1.5 \%$ in the thermal therapy kiln, which met the reference values by quality standards of NIFS in Korea (2017).

Table 4. Proximate Analysis Value of Charcoal Produced from Traditional and Thermal Therapy Kilns

\begin{tabular}{|c|c|c|c|}
\hline & QS & TK & TTK \\
\hline Moisture Content $(\%)$ & $<10$ & $9.80( \pm 0.04)$ & $9.15( \pm 0.01)$ \\
\hline Ash Content $(\%)$ & $<5.5$ & $1.14( \pm 0.03)$ & $1.50( \pm 0.12)$ \\
\hline Volatile Matter $(\%)$ & - & $7.05( \pm 1.69)$ & $9.10( \pm 3.75)$ \\
\hline Fixed Carbon $(\%)$ & - & $82.20( \pm 1.68)$ & $80.19( \pm 3.80)$ \\
\hline
\end{tabular}

QS: Quality standards in NIFS in Korea (2017); TK: Traditional kiln; TTK: Thermal therapy kiln; values in parenthesis are the standard deviations

Kwon et al. (2011) reported the ash content ranges from $1.63 \%$ to $2.71 \%$. Lee and Kim (2010) estimated the ash content to be $2.5 \%$. Thus, the ash content values in this study were similar to values from other studies. The volatile matter of the charcoal from the traditional kiln $(7.05 \%)$ was smaller than that from the thermal therapy kiln $(9.10 \%)$. Hidayat et al. (2017) also reported that the volatile matter of the charcoal from four tropical wood species at $800{ }^{\circ} \mathrm{C}$ ranged from $14.61 \%$ to $22.52 \%$. The fixed carbon of charcoal from the traditional kiln was $82.20 \%$, and $80.19 \%$ from the thermal therapy kiln. Hidayat et al. (2017) also reported that the fixed carbon of charcoal from tropical woods ranged from $73 \%$ to $83 \%$. In the current study, 
the fixed carbon content of produced charcoal from both kilns were not noticeable different from the charcoal used in other studies. In conclusion, the charcoal proximate analysis produced from traditional therapy and thermal therapy kilns met the quality standards of NIFS in Korea (2017).

\section{Comparison of Physical Characteristics and Proximate Analysis of Charcoal Produced Over One Year from Thermal Therapy Kilns}

Table 5 shows the physical properties measured for one year (and displayed by the month of measurement) from thermal therapy kilns, such as density, $\mathrm{pH}$, calorific value, refining degree, and hardness of charcoal. The density of charcoal had variable values over the year. The lowest value was approximately $0.68 \mathrm{~g} / \mathrm{cm}^{3}$ in September, and the highest was approximately $0.74 \mathrm{~g} / \mathrm{cm}^{3}$ in March. The $\mathrm{pH}$ values ranged from 9.45 to 9.77 , which were slightly higher than the charcoal produced from the traditional kiln (Table 3). Kwon et al. $(2012,2013)$ reported that the $\mathrm{pH}$ values of charcoal prepared from oak wood increased with increasing carbonization temperature, changing from acidic to basic. The $\mathrm{pH}$ change might be due to differences in the type and quantities of acidic and basic functional groups, such as carboxylic acid, carboxylic anhydride, lactone, lactol, and pyrone (Boehm 1994, 2002). Hidayat et al. (2017) also noted that the $\mathrm{pH}$ increased with increasing carbonization temperature. The calorific values were approximately $7,761 \mathrm{kcal} / \mathrm{kg}$ to $7,891 \mathrm{kcal} / \mathrm{kg}$, which met the first class standards from the quality standards in NIFS in Korea (2017). The refining degree designates the degree of carbonization of charcoal by measuring electrical resistance at charcoal surface. The refining degree of the charcoal throughout one year was 0 to 1 , which showed that the charcoal had good electric conductance. The hardness of the charcoal throughout the year was 12 . Consequently, the charcoal from the thermal therapy kilns had excellent physical properties that were similar to the charcoal from traditional kilns.

Table 5. Physical Properties Displayed by Month of Charcoal from the Thermal Therapy Kiln

\begin{tabular}{|c|c|c|c|c|c|}
\hline Kiln & $\begin{array}{c}\text { Density } \\
\left(\mathrm{g} / \mathrm{cm}^{3}\right)\end{array}$ & $\mathrm{pH}$ & $\begin{array}{c}\text { Calorific Value } \\
(\mathrm{kcal} / \mathrm{kg})\end{array}$ & $\begin{array}{c}\text { Refining } \\
\text { Degree }\end{array}$ & Hardness \\
\hline TTK (2017.12) & $0.73( \pm 0.02)$ & $9.45( \pm 0.15)$ & 7,761 & 0 to 1 & 12 \\
\hline TTK (2018.03) & $0.74( \pm 0.03)$ & $9.77( \pm 0.17)$ & 7,777 & 0 to 1 & 12 \\
\hline TTK (2018.05) & $0.70( \pm 0.03)$ & $9.61( \pm 0.19)$ & 7,846 & 0 to 1 & 12 \\
\hline TTK (2018.07) & $0.71( \pm 0.02)$ & $9.47( \pm 0.19)$ & 7,805 & 0 to 1 & 12 \\
\hline TTK (2018.09) & $0.68( \pm 0.02)$ & $9.45( \pm 0.43)$ & 7,891 & 0 to 1 & 12 \\
\hline TTK (2018.11) & $0.68( \pm 0.03)$ & $9.51( \pm 0.14)$ & 7,867 & 0 to 1 & 12 \\
\hline Average & $0.71( \pm 0.03)$ & $9.54( \pm 0.13)$ & 7,824 & 0 to 1 & 12 \\
\hline QS & & & First class $>$ & & \\
\hline
\end{tabular}

QS: Quality standards in NIFS in Korea (2017); values in parenthesis are the standard deviations

Table 6 shows the proximate analysis results measured for one year (and displayed by month of measurement) from the thermal therapy kilns, such as moisture content, ash content, 
volatile matter, and fixed carbon of the charcoal. The moisture content of the charcoal was the highest in July $(8.1 \%)$, and the lowest in September (2.2\%). The moisture content was the lowest during the autumn months. The ash content was the highest in March (3.8\%) and the lowest in September (1.9\%). Shin and Kim (2013) reported that the ash content from Quercus phillyraeoides ranged from $3.6 \%$ to $3.7 \%$. Kwon et al. (2012) estimated that the ash content in the surface and the center of charcoal was $2.67 \%$ and $3.10 \%$, respectively. Recently, Hidayat et al. (2017) reported that the ash content of juvenile woods from four tropical wood species after carbonization at $800{ }^{\circ} \mathrm{C}$ ranged from $1.91 \%$ to $3.94 \%$.

The charcoal used in the current study showed a somewhat low ash content in September and November. The volatile matter of charcoal from the thermal therapy kilns were approximately $4.5 \%$ to $6.1 \%$. Shin and Kim (2013) reported that the volatile matter ranged from $5.67 \%$ to $7.65 \%$. In contrast, Lee and Kim (2011) reported that volatile matter ranged from $8.6 \%$ to $11.8 \%$ at $800{ }^{\circ} \mathrm{C}$, which is slightly higher than the values reported in the current study.

The fixed carbon of charcoal from the thermal therapy kilns ranged from $84 \%$ to $90 \%$ over one year. Lee and Kim (2011) reported that the fixed carbon was $79.3 \%$ from $Q$. acutissima and $80.2 \%$ from Q. serrata. Shin and Kim (2013) found that the fixed carbon of charcoal from $Q$. phillyraeoides ranged from $86.31 \%$ to $85.97 \%$. As the carbonization temperature increases, the fixed carbon also increases (Hidayat et al. 2017). Consequently, the results of the proximate analysis of the charcoal were slightly different during the months measured, and the charcoal produced had excellent qualities that met the quality standards set by the NIFS in Korea (2017).

Table 6. Proximate Analysis Values Displayed by Month of Charcoal from Thermal Therapy Kilns

\begin{tabular}{|c|c|c|c|c|}
\hline Kiln & $\begin{array}{c}\text { Moisture } \\
\text { Content (\%) }\end{array}$ & Ash Content $(\%)$ & $\begin{array}{c}\text { Volatile Matter } \\
(\%)\end{array}$ & $\begin{array}{c}\text { Fixed Carbon } \\
(\%)\end{array}$ \\
\hline TTK (2017.12) & $5.4( \pm 0.5)$ & $3.1( \pm 0.3)$ & $6.1( \pm 0.3)$ & 85.4 \\
\hline TTK (2018.03) & $5.8( \pm 0.3)$ & $3.8( \pm 0.1)$ & $4.6( \pm 0.7)$ & 85.8 \\
\hline TTK (2018.05) & $6.6( \pm 0.3)$ & $2.8( \pm 0.5)$ & $4.7( \pm 0.4)$ & 85.9 \\
\hline TTK (2018.07) & $8.1( \pm 0.6)$ & $2.8( \pm 0.4)$ & $4.5( \pm 1.1)$ & 84.6 \\
\hline TTK (2018.09) & $2.2( \pm 0.7)$ & $1.9( \pm 0.1)$ & $5.2( \pm 0.3)$ & 90.7 \\
\hline TTK (2018.11) & $2.4( \pm 0.5)$ & $2.1( \pm 0.3)$ & $4.8( \pm 0.2)$ & 90.7 \\
\hline Average & $5.1( \pm 2.3)$ & $2.8( \pm 0.7)$ & $4.3( \pm 1.9)$ & 87.2 \\
\hline QS & $<10$ & $<5.5$ & & \\
\hline
\end{tabular}

QS: Quality standards in NIFS in Korea (2017); values in parenthesis are the standard deviations

\section{CONCLUSIONS}

1. The ceramic bricks for the materials constructing thermal therapy kiln were more effective for far-infrared emissivity and radiation energy than the red clay and red clay bricks.

2. For a safe and clean thermal therapy kiln, a modified kiln was designed with two doors, 
noxious gas barriers, and a fine dust collector. The amount of fine dust and harmful substances in the kiln met the reference value set by the Clean Air Conservation Act from the Ministry of Environment Act No. 13034 (2015).

3. The physical characteristics and proximate analysis of charcoal taken from the traditional and thermal therapy kilns showed no considerable differences and satisfied the quality standard specified in the NIFS of Korea (2017).

4. The results of the physical properties and proximate analyses of charcoal produced from the thermal therapy kilns over one year showed no noticeable differences, and met the quality standards contained in the NIFS of Korea (2017).

\section{ACKNOWLEDGMENTS}

This study was supported by the Forest Science and Technology Research and Development Project (No: 2016008A00-1919-AB01) provided by the Korea Forest Service.

\section{REFERENCES CITED}

Boehm, H. P. (1994). "Some aspects of the surface chemistry of carbon blacks and other carbons," Carbon 32(5), 759-769. DOI: 10.1016/0008-6223(94)90031-0

Boehm, H. P. (2002). "Surface oxides on carbon and their analysis a critical assessment," Carbon 40(2), 145-149. DOI: 10.1016/S0008-6223(01)00165-8

Hidayat, W., Qi, Y., Jang, J. H., Febrianto, F., Lee, S. H., Chae, H. M., Kondo, T., and Kim, N. H. (2017). "Carbonization characteristics of juvenile woods from some tropical trees planted in Indonesia," Journal of the Faculty of Agriculture Kyushu University 62(1), $145-152$.

JIS Z 8806 (2001). “Humidity- Measurement methods," Japanese Standards Association, Tokyo, Japan.

Jo, T. S., Choi, J. W., and Lee, O. K. (2007). "Physicochemical changes of woody charcoals prepared by different carbonizing temperature," Journal of the Korean Wood Sciences and Technology 35(3), 53-60.

Jo, T. S., Lee, O. K., Choi, J. W., and Byun, J. K. (2008). “Adsorption of cadmium ion by wood charcoal prepared with red oak (Quercus mongolica)," Journal of the Korean Wood Sciences and Technology 36(3), 93-100. DOI: 10.5658/WOOD.2013.41.3.181

Kim, N. H. (2015). A Study on the Practical Utilization to Thermal Therapy of Charcoal Kiln for Revitalization of the Traditional Wood Charcoal Industry, Korea Forest Service, Daejeon, Republic of Korea.

KS E ISO 562 (2017). "Hard coal and coke - Determination of volatile matter," Korean Standards Association, Seoul, Republic of Korea.

KS E ISO 589 (2017). "Hard coal - Determination of total moisture," Korean Standards Association, Seoul, Republic of Korea.

KS E ISO 1171 (2017). "Solid mineral fuels - Determination of ash content," Korean Standards Association, Seoul, Republic of Korea.

Kwon, G. J., Kwon, S. M., Jang, J. H., Hwang, W. J., and Kim, N. H. (2011). “Charcoal properties and temperature change of a kiln's inner and outer walls in carbonization process using an improved kiln," Journal of the Korean Wood Sciences and Technology 
39(3), 230-237. DOI: 10.5658/WOOD.2011.39.3.230

Kwon, S. M., Jang, J. H., Lee, S. H., Park, S. B., and Kim, N. H. (2013). "Change of heating value, $\mathrm{pH}$ and FT-IR spectra of charcoal at different carbonization temperatures," Journal of the Korean Wood Sciences and Technology 41(5), 440-446. DOI: 10.5658/WOOD.2013.41.5.440

Kwon, S. M., Kwon, G. J., Jang, J. H., and Kim, N. H. (2012). "Characteristics of charcoal in different carbonization temperatures," Journal of Forest Science 28(4), 263-267. DOI: 10.7747/JFS.2012.28.4.263

Lee, D. Y., and Kim, B. R. (2010). "Adsorption characteristics of commercial wood charcoal (I)," Journal of the Korean Wood Sciences and Technology 38(1), 27-35. DOI: 10.5658/WOOD.2010.38.1.27

Lee, D. Y., and Kim, B. R. (2011). "Adsorption characteristics of charcoal from major Korean wood species and wood-based materials (II)," Journal of the Korean Wood Sciences and Technology 39(4), 281-290. DOI: 10.5658/WOOD.2011.39.4.281

Leung, T. K., Lee, C. M., Tsai, S. Y., Chen, Y. C., and Chao, J. S. (2011). "A pilot study of ceramic powder far-infrared ray irradiation (cFIR) on physiology: Observation of cell cultures and amphibian skeletal muscle," Chinese Journal of Physiology 54(4), 247-254. DOI: 10.4077/CJP.2011.AMM044

Mai, H. N., Sharma, N., Shin, E. J., Nguyen, B. T., Jeong, J. H., Jang, C. H., Cho, E. H., Nah, S. Y., Kim, N. H., Nabeshima, T., et al. (2018a). "Exposure to far infrared ray protects methamphetamine-induced behavioral sensitization in glutathione peroxidase-1 knockout mice via attenuating mitochondrial burdens and dopamine D1 receptor activation," Neurochem. Res. 43(5), 1118-1135. DOI: 10.1007/s11064-018-2528-5

Mai, H. N., Sharma, N., Shin, E. J., Nguyen, B. T., Jeong, J. H., Jang, C. G., Cho, E. H., Nah, S. Y., Kim, N. H., Nabeshima, T., et al. (2018b). "Exposure to far-infrared ray attenuates methamphetamine-induced recognition memory impairment via modulation of the muscarinic M1 receptor, Nrf2, and PKC," Neurochemistry International 116, 63-76. DOI: 10.1016/j.neuint.2018.03.009

Ministry of Environment Act No. 13034 (2015). "Clean air conservation act (Enforcement Date 21 July 2015),” Ministry of Environment, Sejong City, Korea.

National Institute of Forest Science (2017). Standard and Specification of Wood Products (Notification No. 2017-9), Korea Forest Service, Seoul, Korea.

Shin, S. J., and Kim, B. R. (2013). "Analysis of charcoal from Quercus phillyraeoides," Journal of the Korean Wood Sciences and Technology 41(3), 181-186. DOI: 10.5658/WOOD.2013.41.3.181

Article submitted: February 12, 2019; Peer review completed: May 27, 2019; Revised version received: June 20, 2019; Accepted: June 21, 2019; Published: July 30, 2019.

DOI: 10.15376/biores.14.3.7275-7284 